\title{
DEPLOYABLE STRUCTURES AS SUPPORTS FOR LIGHT GAUGE STEEL SHELLS
}

\begin{abstract}
The paper concerns using deployable bar structures as basic parts of structural systems of light gauge steel compound shells. Applying such structural systems should improve the shells assembly because of exploiting: a) planes and nodes appointed by pairs of intersecting bars to set directrices of their individual shells, b) prefabrication of their structural systems. Thus, the main aim of using the deployable bar structure is to get the ends of its bars at the expected nodes after lying it out but not continuity of this structure or constancy of the positions of the flexible joints on the length of its bars during unfolding/unfolding. Such a structure has not to let itself fold to a linear shape and unfold to a planar one. The presented issues are a ground for studying a method of shaping light gauge steel shells supported with the changeable bar structures, which allows for creating free and original shell forms. In the paper, the author applies auxiliary, conceive and continue tetrahedral pyramids to get structures, whose general forms approximate spheres. The examined example shows that it is possible to change a type of the auxiliary tetrahedral compositions to get a variety of original shell forms by differentiation of the lengths and divisions of the bars as well as by disconnecting chosen ends of a few bars or using the flexible joints which are able to change their position on the length of chosen bars.
\end{abstract}

Keywords: geometrical shaping, compound structures, bar structures, shell structures

\section{Introduction - peculiar properties of light gauge steel shells}

The paper presents geometrical shaping deployable structural bar systems of light gauge steel shells made of flat trapezial steel sheets similar to each other. These sheets are joined with their longitudinal edges in a flat strip, and next, after lying out on directrices, transformed to spatial forms (see Fig. 1).

The flat sheet can be easily transformed to a spatial shape, which depends on its physical and geometrical properties as well as a mutual position and shape of the supporting directrices [1]. Because of its unidirectional corrugation, the

\footnotetext{
${ }^{1}$ Autor do korespondencji: Jacek Abramczyk, Rzeszow University of Technology, 2 Poznanska Street, 35-959 Rzeszow, tel. +48 17 8651307, jacabram@ prz.edu.pl.
} 
sheet is characterized by great longitudinal stiffness, so even after transformation to the shell shape the axes of its folds remain rectilinear. Every individual shell is characterized by a contraction in the middle of the length of its folds and its form is compatible with properties of a ruled surface (see Fig. 2).

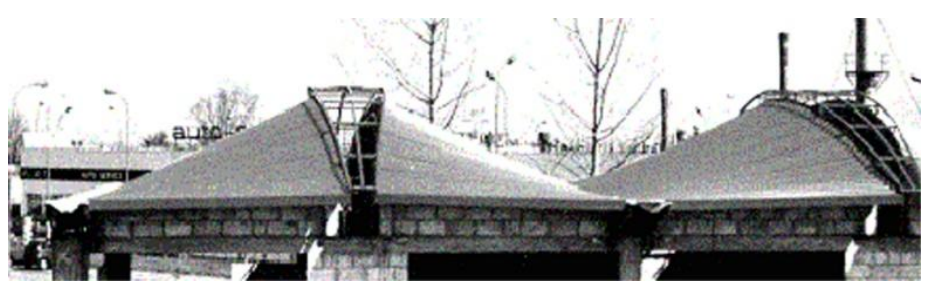

Fig. 1. The multi-segment shell structure [2]

Rys. 1. Wielosegmentowa struktura powłokowa [2]

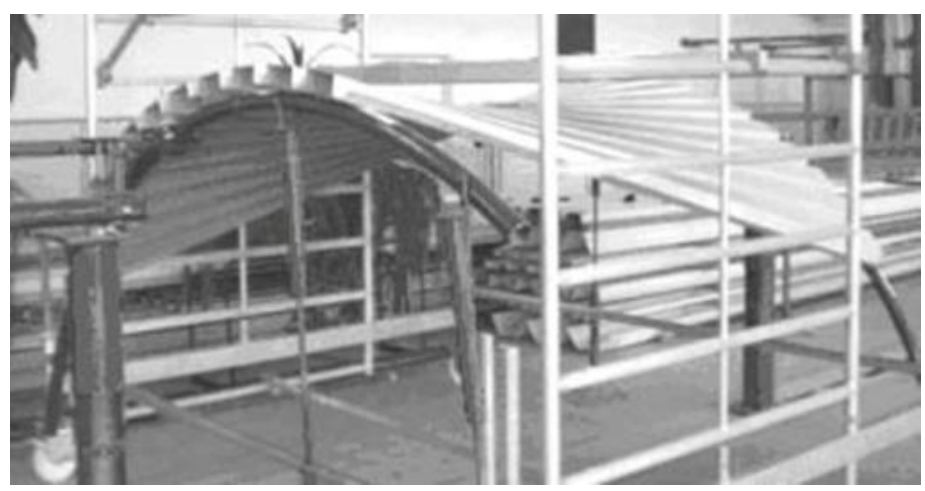

Fig. 2. The single shell made up of the free deformed flat sheets

Rys. 2. Pojedyncza powłoka wykonana ze swobodnie zdeformowanych płaskich arkuszy

The examined shell sheets have to undergo such a transformation during which the freedom of the transversal width increments of their folds, being the result of this transformation, is assured. This transformation is called free deformation. It is the initial folds deformation before loading a shell. The specificity of these changes consists in decreasing the width of the fold in its half length and increasing the fold ends width along the directrices.

From the character of the above changes it results the fact, that two adjacent such transformed shells cannot be connected one to the another by their crosswise ends to obtain a smooth resultant shell [3]. They can be put together into a complex shell by leaning their crosswise edges against: a) the shared directrix to get a continuous structure whose characteristics are rectilinear or curvilinear edges disturbing the smoothness of the complex shell (see Fig. 4), 
b) various, mutually displaced or turned directrices to receive a discontinuous structure which is characterized, for example, by flat areas of discontinuity (see Fig. 3) [1].

Fig. 3. The discontinue shell structure

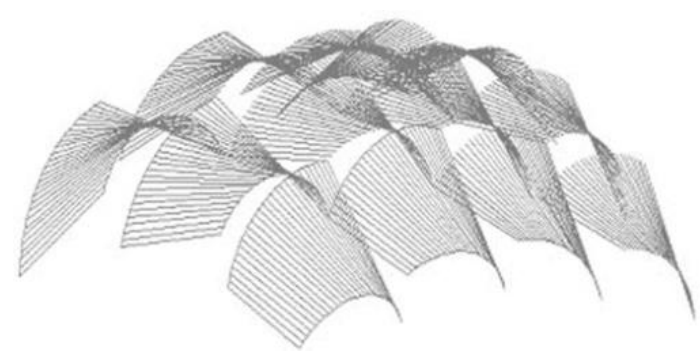

Rys. 3. Nieciagła struktura powłokowa

It is possible to create shell structures of various types characterized by free original forms which are composed of individual shells called the segments and located in three-dimensional space according to initially accepted various base surfaces characterized by any sign of the Gaussian curvature [4]. Algorithms of action used by elaborated ways permit to distinguish two stages in the process of shaping an expected structure. In the first stage, the way enables allocating tetrahedral "cells" in three-dimensional space. In the examined example (see Fig. 4) the tetrahedral "cells" are reduced to the lateral surfaces of a pyramids called the pyramid tetrahedrons. In the second stage, the segments have to be created in the interior of these pyramid tetrahedrons (see Fig. 4). The controlling structure is a sum of the pyramid tetrahedrons also called the controlling tetragonal pyramids $[2,4]$. These pyramids are separated from each other with planes. It is possible to use these planes as the ones which contain pairs of bars of a deployable structure in an expected location, that is, in which the structure can be accepted as a part of the structural system of the shell structure.
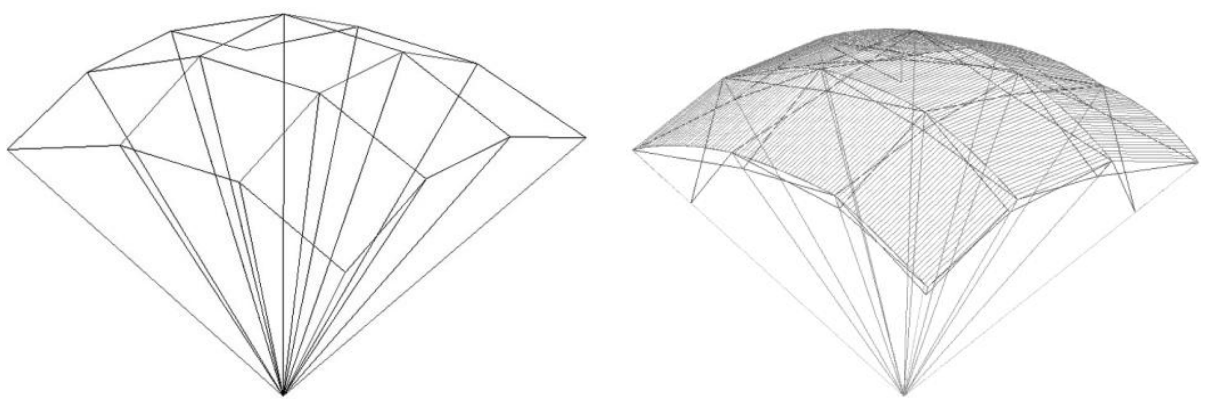

Fig. 4. The continue shell structure supported with the deployable structural system and created on the base of a system of pyramids

Rys. 4. Układ ostrosłupów i model struktury powłokowej podpartej strukturą prętową 


\section{Possibility and restrictions in shaping free forms of shell structures supported with deployable bar systems}

From the works $[3,4]$ it results the fact that a shell structure can take a general form approximate any regular surface in the range of curvature most often used in constructions. But if it is supported with deployable bar structure, then the diversity of its possible forms will be radically limited. The known deployable structures, which have been erected until now, are approximated to chosen types of regular surfaces including sphere, paraboloid, rotational or translation surfaces $[5,6]$. The works accessible to the author don't refer to light gauge shells composed of flat steel sheets transformed to spatial shapes.

The assumption concerning the assurance of the freedom of the transversal width increments of all shell folds makes troubles connected with calculating suitable widths of transversal folds ends and length of shell directrices.

It was accepted that the main aim of using a deployable bar structure is to get the ends of its bars of adjacent pairs at the expected shared nodes after laying it out. Proper points and planes of the unfolded deployable structure are used for appointing planes and joints of the directrices. The assembly of additional bars and ties in final stage improving the resistance of the shell structural system to dead load is intentional.

The individual bar section and its auxiliary pyramid with the vertex $\mathrm{W}$ is presented in the figure (see Fig. 5). Let us assume that the 9-sectional deployable structure of identical length bars ought to be shaped. First five segments being lain orthogonally in the structure (see Fig. 6) have to be built with bars of identical length and having the same division done by flexible joints. However, last four sections have to be lain diagonally and they may be shaped with bars of other divisions and the same lengths.

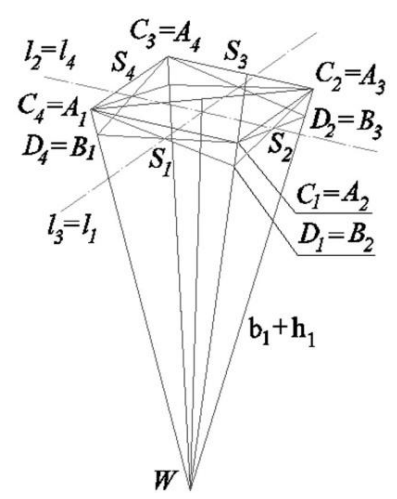

Fig. 5. The single bar section with the auxiliary pyramid tetrahedron

Rys. 5. Pojedynczy układ prętowy z pomocniczym czworościanem ostrosłupowym

Thus each deployable structure is composed of many single bar sections and every section consists of four pairs of bars. The bars of one pair cross each other at their intermediate points, close to their centre points. They are exclu- 
sively turned around the shared axis perpendicular to the plane of these bars and passing through the point of their intersection. The ends of the bars of the neighbouring pairs are joined by flexible joints, which ensures the continuity of the structure while unfolding or folding caused by the change of a rotation angle of every pair of bars. Each pair of the bars fixes a "conceivable" triangle called the auxiliary triangle. A sum of four such triangles fixed for each of the bar sections is the lateral surface of a pyramid. All four side edges of each pyramid tetrahedron have to intersect each other at the same vertex and it is called the auxiliary pyramid tetrahedron. In generall, it is said to be the auxiliary tetrahedron. In the case of well-known deployable structures, presented for example in works [5, 7] the author is able to find auxiliary tetrahedrons of a pyramid, prism or cuboidal type.

Fig. 6. The structure of the 5 sections of the pyramid type arranged in orthogonal directions

Rys. 6. Struktura pięciu układów prętowych typu ostrosłupowego rozmieszczonych w ortogonalnych kierunkach

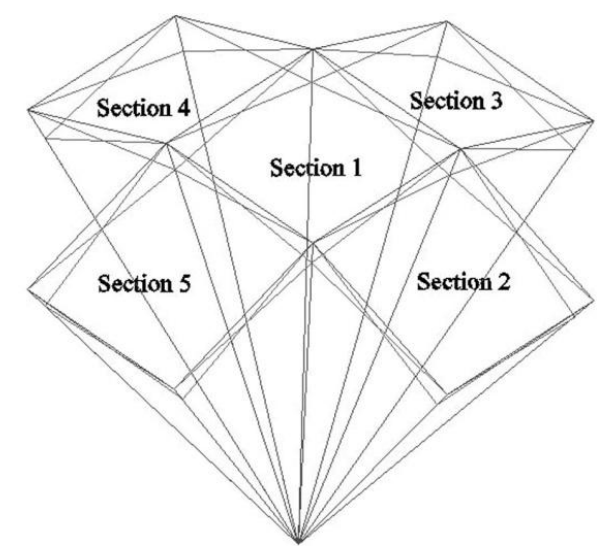

By changing a mutual position of the bars of one pair we also cause a change of angles of inclination of the remaining bars of both the single section as well as a change of the entire structure. At the same time, geometrical properties of the auxiliary tetrahedrons - the property and mutual position of the triangular faces of the tetrahedrons also change. In addition, the structure and the tetrahedron preserve continuity during these changes.

However, the main assumption concerns the fact that triangular faces of each auxiliary tetrahedron have to have one changeable common point - the tetrahedron vertex. Mutual positions of its faces and their geometrical properties also change by preserving the continuity along their common edges. Additionally, if we take the assumption that all bars of the pyramid tetrahedron are of an identical length and it appears only one their division, then it will be possible to create exclusively bar structure unfolding to the spherical form and having a few symmetry planes. In extreme cases it can be unfolded to the flat shape and folded to the linear one.

Because the light gauge shell structures can take almost free forms, [3, 4], which are really diversified but not only similar to multi-symmetrical segments 
of a sphere, then it is also desirous to getting the great diversity of forms of deployable structures supporting them at the cost of the diversity of lengths and divisions of bars.

In order to increase the diversity of forms of the shell structures supported with deployable bars, the changes of the division ratio of the chosen bars from among $A_{i} D_{i}$ and $B_{i} C_{i}$ with the flexible joins $S_{i}$ while spreading the deployable structure were accepted (see Fig. 7).<smiles></smiles>

It requires carrying out appropriate joints of physical constructions changing their positions along appropriate bars along with the change of the angle $\gamma_{1}$ between the bars. Such action constitutes the preliminary stage for elaborating the way of creating diversified forms of shell structures supported with deployable bar structures different from spherical shapes [7], where the following conditions: $a_{i}+d_{i}=$ const and $b_{i}+c_{i}=$ const have to be performed for the bars.

\section{Principles of shaping a deployable part of a structural system}

The demonstrative figure (see Fig. 5) presents the single bar section with the auxiliary right pyramid having the vertex W. A 9-sectional structure composed of identical bars is sought. The first five sections arranged in orthogonal directions in the structure will be built by preserving their identical divisions carried out by flexible joints (see Fig. 8). However, the last four
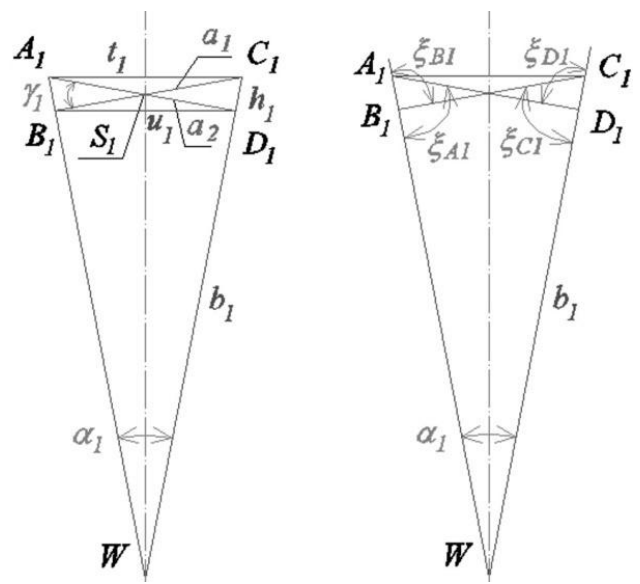

Fig. 8. The face of the auxiliary tetrahedron together with the pair of bars

Rys. 8. Ściana pomocniczego czworościanu wraz z parą prętów sections arranged in diagonal direc- 
tions can be built with using another divisions (see Figs. 9-12).

Pairs of bars assign four planes which intersects each other in straight lines containing the side edges of the auxiliary pyramid tetrahedron (see Fig. 5).

These edges allocate four angles $\alpha_{i}$ of characterized by the common vertex $\mathrm{W}$. If we change the angle $\gamma_{i}=\gamma_{1}$ of inclination of one pairs of the section, then we will change the angles of inclination of the remaining pairs with keeping the continuity of the section at all shared ends of bars of the neighbouring pairs. The mutual location of bars, the section form as well as the geometrical properties of the auxiliary pyramid tetrahedron are changed together with the angle $\gamma_{1}$. The lengths and divisions of bars with the points $S_{i}$ do not change.

Let us assume that geometrical objects will be denoted in italics, for example $\alpha_{i}, \gamma_{1}$, but variables and their values will be in mathematics, for example $\gamma_{i}=\gamma_{1}$.

The following algorithm leading to creating an individual bar section of orthogonal stripes along with the auxiliary tetrahedron was elaborated. The quotient $\frac{\mathrm{a}_{1}}{\mathrm{a}_{2}}=\mathrm{a}_{\mathrm{x}}$ and the length a of all bars was accepted. The dependence between a location of four pairs of bars of a section of the above presented type and geometrical properties each of its auxiliary pyramid tetrahedron is described by (1)(8) (see Fig. 8).

We assume that

$$
\begin{aligned}
& a_{1}=A_{1} S_{1}=S_{1} C_{1} \\
& a_{2}=B_{1} S_{1}=S_{1} D_{1} \\
& a_{1}+a_{2}=a, A_{1} B_{1}=D_{1} C_{1}=h_{1}
\end{aligned}
$$

From the properties of the triangle $A_{1} S_{1} B_{1}$ they follow:

$$
\begin{aligned}
& A_{1} B_{1}=D_{1} C_{1}=h_{1}=\sqrt{a_{1}^{2}+a_{2}^{2}-2 \cdot a_{1} \cdot a_{2} \cdot \cos \gamma_{1}} \\
& a_{2}^{2}=a_{1}^{2}+h_{1}^{2}-2 \cdot a_{1} \cdot h_{1} \cdot \cos \xi_{A 1}
\end{aligned}
$$

From the properties of the triangle $A_{1} D_{1} W$ we get (6):

$$
\mathrm{b}_{1}^{2}=\left(\mathrm{b}_{1}+\mathrm{h}_{1}\right)^{2}+\left(\mathrm{a}_{1}+\mathrm{a}_{2}\right)^{2}-2 \cdot\left(\mathrm{b}_{1}+\mathrm{h}_{1}\right) \cdot\left(\mathrm{a}_{1}+\mathrm{a}_{2}\right)
$$

On the base of (3) and the accepted quotient $\mathrm{a}_{\mathrm{x}}$ we can calculate the variable $\mathrm{a}_{1} \mathrm{i} \mathrm{a}_{2}$. From (4) the variable $\mathrm{h}_{1}$ and from (5) the measure of the angle $\xi_{\mathrm{Al}}$ can be calculated. 


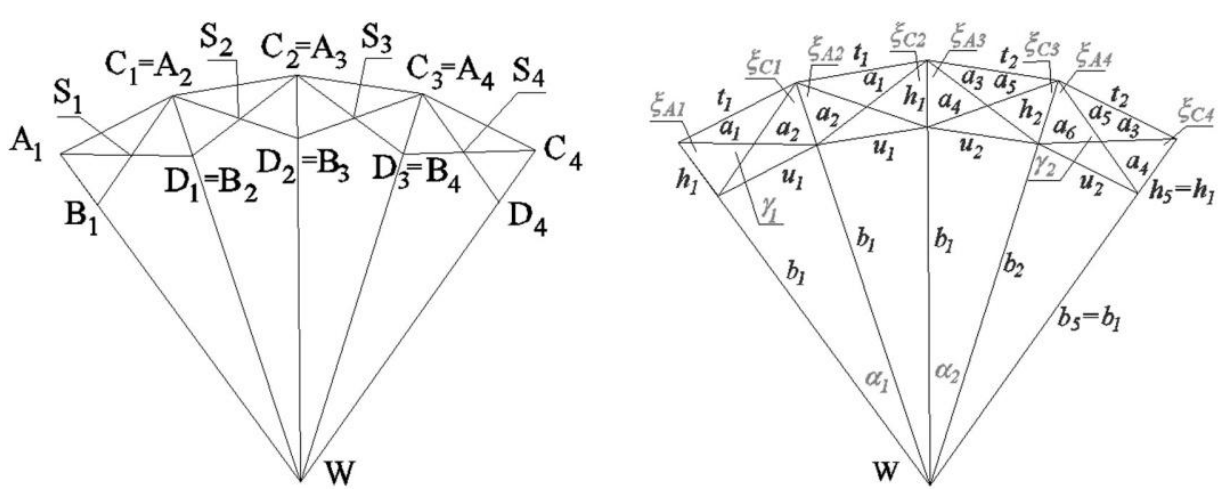

Fig. 9. The development of four faces of the additional section and its auxiliary pyramid tetrahedron

Rys. 9. Rozwinięcie czterech ścian dodatkowego układu prętowego i jego ostrosłupowego czworościanu

In order to create the auxiliary pyramid tetrahedron which is helpful in creating a bar section, we ought to fix a square whose edge length $t_{1}$ can be calculated from (7) based on the properties of the triangle $A_{1} C_{1} W$, where: the angle $\alpha_{1}$ can be calculated from (8) assigned on the base of the triangle $A_{1} D_{1} W$.

$$
\begin{aligned}
& \mathrm{t}_{1}=2 \cdot\left(\mathrm{b}_{1}+\mathrm{h}_{1}\right) \cdot \sin \frac{\alpha_{1}}{2} \\
& \left(\mathrm{a}_{1}+\mathrm{a}_{2}\right)^{2}=\left(\mathrm{b}_{1}+\mathrm{h}_{1}\right)^{2}+\mathrm{b}_{1}^{2}-2 \cdot\left(\mathrm{b}_{1}+\mathrm{h}_{1}\right) \cdot \mathrm{b}_{1} \cdot \cos \alpha_{1}
\end{aligned}
$$

Next, the straight line normal to the plane of this square should be led through the square centre. The vertex $\mathrm{W}$ should be fixed in this line in the distance $b_{1}+h_{1}$ from the square vertices $A_{i}(i=1-4)$ (Fig. 5). The vertices $B_{i}$ ought to be measured out on the straight lines $\left(\mathrm{W}, \mathrm{A}_{\mathrm{i}}\right)$ in the distances $\mathrm{h}_{1}$ from the points $A_{i}$ in the direction to the point $W$. The vertices $C_{i}$ and $D_{i}$ can be accepted on the base of the above $A_{i}$ and $B_{i}$ points.

The deployable structure (Fig. 6) was obtained as the result of setting five identical bar sections with using auxiliary pyramid tetrahedrons of the presented above type. It can be folded to a linear form and unfolded to a flat one.

The obtained 5-sectional deployable structure is going to be extended to the 9 -sectional structure with four additional sections being lain diagonally in it.

In order to get such a 9-sectional structure the following activities ought to be conducted. The bars of the 5-sectional structure are of the same length and have an identical division. However, two additional divisions: $a_{3}, a_{6}$ and $a_{4}, a_{5}$ were executed in the newly created four Sections 6 to 9.

As a result, two types of triangular faces of the new additional pyramid tetrahedron were received. Two its faces are shared with the 5-segmental structure 
being got before. Two remaining faces of each diagonal auxiliary tetrahedron are congruent. The development of all four faces of the additional section was shown in the figure (Fig. 9) where the faces $\mathrm{A}_{1} \mathrm{~A}_{2} \mathrm{~W}$ and $\mathrm{A}_{3} \mathrm{~A}_{2} \mathrm{~W}$ are common with the 5-sectional structure.

In order to create the Section 6 (Fig. 10), that is lain diagonally in a 9-sectional structure being continuous while changing the angle $\gamma_{1}$, the relations: $\mathrm{A}_{1} \mathrm{~B}_{1}=\mathrm{h}_{1}=\mathrm{C}_{4} \mathrm{D}_{4}=\mathrm{h}_{5}=\mathrm{A}_{3} \mathrm{~B}_{3}=\mathrm{h}_{3}=\mathrm{A}_{2} \mathrm{~B}_{2}=\mathrm{h}_{2}, \mathrm{WB}_{1}=\mathrm{b}_{1}=\mathrm{WB}_{4}=$ $=b_{5}=W_{3}=b_{3}=W_{2}=b_{2}$ (Fig. 9) have to be preserved. Additionally, it was accepted the fact that the triangles $\mathrm{WA}_{4} \mathrm{C}_{4}$ and $\mathrm{WA}_{3} \mathrm{C}_{3}$ have to be congruent and the lengths $b_{2}, h_{2}$ of their shared edge may be different from the values $b_{1}, h_{1}$. On the base of the above dependences, the system (*) composed of (9)-(15), whose independent variables are: $b_{1}, a_{1}, a_{2}, a_{3}, h_{1}$ and dependent variables are: $b_{2}, a_{4}, a_{5}$, $\mathrm{h}_{2}, \xi_{\mathrm{A} 4}, \xi_{\mathrm{C} 4}, \gamma_{2}$ was created.

Fig. 10. Sections 6 and 7 being lain diagonally in the structure

Rys. 10. Układy 6 i 7 położone diagonalnie w strukturze

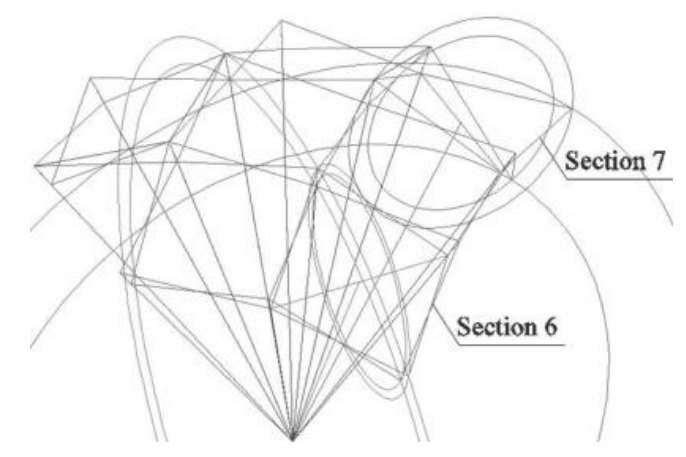

From the properties of the triangle $\mathrm{WB}_{4} \mathrm{C}_{4}$ it follows:

$$
\mathrm{b}_{2}^{2}=\left(\mathrm{b}_{1}+\mathrm{h}_{1}\right)^{2}+\left(\mathrm{a}_{3}+\mathrm{a}_{6}\right)^{2}-2 \cdot\left(\mathrm{b}_{1}+\mathrm{h}_{1}\right) \cdot\left(\mathrm{a}_{3}+\mathrm{a}_{6}\right) \cdot \cos \xi_{\mathrm{c} 4}
$$

where $b_{1}=b_{5}, h_{1}=h_{5}$.

From the properties of the triangle $\mathrm{C}_{4} \mathrm{~S}_{4} \mathrm{D}_{4}$ it results:

$$
\cos \left(\xi_{\mathrm{C} 4}\right)=\frac{\mathrm{h}_{1}^{2}+\mathrm{a}_{3}^{2}-\mathrm{a}_{4}^{2}}{2 \cdot \mathrm{h}_{1} \cdot \mathrm{a}_{3}}
$$

where: $h_{1}=h_{5}$.

Equation (11) follows from the properties of the triangle $\mathrm{WD}_{4} \mathrm{~A}_{4}$.

$$
\mathrm{b}_{1}^{2}=\left(\mathrm{b}_{2}+\mathrm{h}_{2}\right)^{2}+\left(\mathrm{a}_{4}+\mathrm{a}_{5}\right)^{2}-2 \cdot\left(\mathrm{b}_{2}+\mathrm{h}_{2}\right) \cdot\left(\mathrm{a}_{4}+\mathrm{a}_{5}\right)
$$

where $b_{1}=b_{5}$. 
From the properties of the triangle $\mathrm{A}_{4} \mathrm{~S}_{4} \mathrm{~B}_{4}$ we get:

$$
\cos \left(\xi_{\mathrm{A} 4}\right)=\frac{\mathrm{h}_{2}^{2}+\mathrm{a}_{5}^{2}-\mathrm{a}_{6}^{2}}{2 \cdot \mathrm{h}_{2} \cdot \mathrm{a}_{5}}
$$

To get (13) we have to examine properties of the triangle $\mathrm{C}_{3} \mathrm{~S}_{3} \mathrm{D}_{3}$.

$$
\mathrm{h}_{2}=\sqrt{\mathrm{a}_{5}^{2}+\mathrm{a}_{6}^{2}-2 \cdot \mathrm{a}_{5} \cdot \mathrm{a}_{6} \cdot \cos \gamma_{2}}
$$

From the properties of the triangle $A_{3} S_{3} B_{3}$ we have:

$$
\cos \left(\gamma_{2}\right)=\frac{\mathrm{a}_{3}^{2}+\mathrm{a}_{4}^{2}-\mathrm{h}_{1}^{2}}{2 \cdot \mathrm{a}_{4} \cdot \mathrm{a}_{3}}
$$

where $h_{1}=h_{5}$.

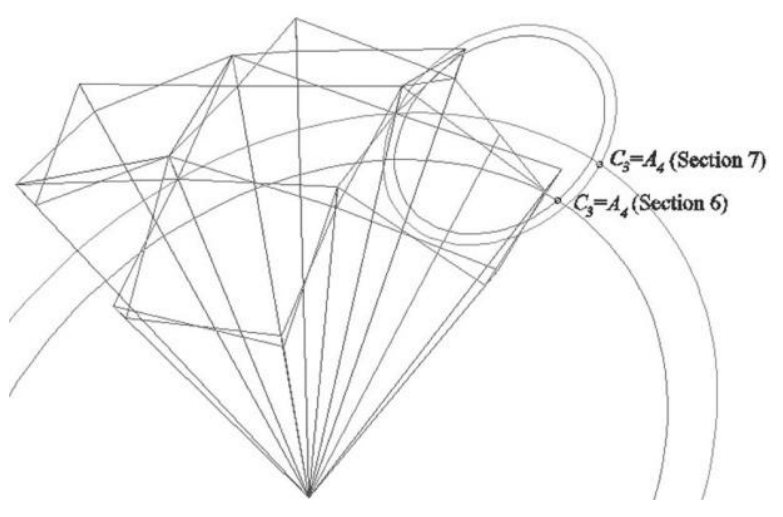

Fig. 11. The differentiation of geometrical properties of Sections 6 and 7

Rys. 11. Zróżnicowanie geometrycznych właściwości układów 6 i 7

The length of all bars of the 9-sectional structure is identical. Hence the equation (15) is appeared in the system $(*)$.

$$
\mathrm{a}_{5}=\mathrm{a}_{1}+\mathrm{a}_{2}-\mathrm{a}_{4}
$$

The value $\mathrm{a}_{6}$ can be calculated from the eq. (16).

$$
a_{6}=a_{1}+a_{2}-a_{3}
$$

For the purpose of fixing the last four Sections 6 to 9 the following assumptions were taken. These four sections ought to be congruent in pairs. Two among them, that is, The Sections 7 and 9 have to be identical ones and the division of their bars will be identical as in Sections 1 to 5 (Figs. 10, 12). The above sections are different from the Sections 1 to 5 because of the angles of inclination 
between the auxiliary tetrahedrons planes. However, the Sections 6 and 8 have other divisions: constant $\frac{\mathrm{a} 3}{\mathrm{a} 6}=\frac{1}{3}$ and changeable $\frac{\mathrm{a} 4}{\mathrm{a} 5}$ dependent on the angle aperture $\gamma_{1}$.

The characteristic feature distinguishing examined structure from the ones presented in available works, for example in $[6,7]$ is the fact, that it can only be of a multi-symmetrical spherical or rotational form. Such a possibility results from the assumption that it is possible to change the division ratio $\frac{\mathrm{a} 4}{\mathrm{a} 5}$ of chosen bars together with the changes of the angle aperture $\gamma_{1}$. The above assumption constrain to work out practical solutions of such a changeable joints. Such a joint has to be constant on the length of the bar $\mathrm{A}_{3} \mathrm{D}_{3}$ and it has to be able to change its position on the length the bar $\mathrm{B}_{3} \mathrm{C}_{3}$ along with the change of the angle aperture $\gamma_{1}$. A description of creating such a phisical the joints goes beyond the scope of the work.

Characteristics of the presented 9-sectional structure were calculated from the system ${ }^{*}$ ) for the angle of the measure $\gamma_{1}=20.4361^{\circ}$ and they are shown in Table 1.

Table 1. Characteristics of the bar structure

Tabela 1. Charakterystyka struktury prętowej

\begin{tabular}{|c|c|c|c|}
\hline Variable & Value $[\mathrm{m}]$ or $\left[{ }^{0}\right]$ & Variable & Value $[\mathrm{m}]$ or $\left[\left[^{\circ}\right]\right.$ \\
\hline$a_{1}$ & 3.10407 & $\xi_{\mathrm{A} 1}$ & 68.88854 \\
\hline $\mathbf{a}_{2}$ & 2.89593 & $\alpha_{1}$ & 21.78682 \\
\hline $\mathbf{a}_{3}$ & 1.50000 & $\xi_{\mathrm{A} 4}$ & 62.39379 \\
\hline $\mathbf{a}_{4}$ & 1.17657 & $\xi_{\mathrm{C} 4}$ & 51.13234 \\
\hline $\mathbf{a}_{5}$ & 4.82343 & $\alpha_{2}$ & 20.64417 \\
\hline$a_{6}$ & 4.50000 & $\mathbf{t}_{1}$ & 6.10968 \\
\hline$h_{1}$ & 1.08390 & $u_{1}$ & 5.70000 \\
\hline$h_{2}$ & 3.64240 & $t_{2}$ & 5.96643 \\
\hline$b_{1}$ & 15.08076 & $\mathbf{u}_{2}$ & 5.38635 \\
\hline $\mathbf{b}_{2}$ & 13.25035 & $\mathbf{v}$ & 4.69814 \\
\hline$\gamma_{1}$ & 20.4361 & $\mathbf{w}$ & 3.88398 \\
\hline$\gamma_{2}$ & 45.8297 & d & 7.46390 \\
\hline
\end{tabular}

The diversification of the properties of Sections 6 and 7 is depicted in the figure (Fig. 11) on the example of diversified locations of the chosen points $\mathrm{C}_{3}=\mathrm{A}_{4}$ of these sections.

However, the diagonal arrangement of Sections 6 and 7 in the structure is presented in the figure, Fig. 10. A way of setting positions of the points $C_{3}=A_{4}$ and $\mathrm{D}_{3}=\mathrm{B}_{4}$ of Section 6 on the basis of the points common to this section and 
earlier created Sections 1 to 3 of the bar structure (Figs. 6, 10) is shown in the figure (Fig. 12).

The point $C_{3}=A_{4}$ we get at the intersection of the circle $\mathrm{O}_{2}$ having the centre in the point $\mathrm{T}$ - the centre of the section $\mathrm{B}_{3} \mathrm{~B}_{1}$ and the radius $v$ and the circle $\mathrm{o}_{3}$ having the centre in the point $\mathrm{W}$ and the radius $\mathrm{b}_{2}+\mathrm{h}_{2}$. However, the point $\mathrm{D}_{3}$ $=\mathrm{B}_{4}$ is lain at the intersection of the circle $\mathrm{o}_{1}$ having the centre in the point $\mathrm{T}$ and the radius $w$ and the circle $\mathrm{o}_{4}$ having the centre in the point $\mathrm{W}$ and the radius $\mathrm{b}_{2}$. All these circles are lain on the plane passing through the point $T$ and perpendicular to the straight line $\left(\mathrm{B}_{3}, \mathrm{~B}_{1}\right)$.
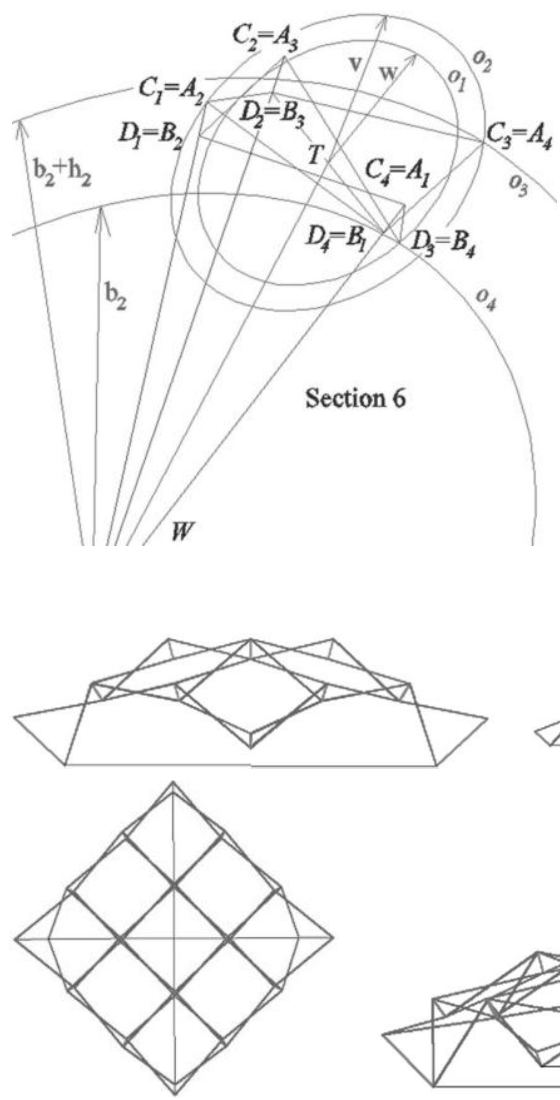

Fig. 12. The way of creating Section 7

Rys. 12. Sposób wyznaczania układu 7
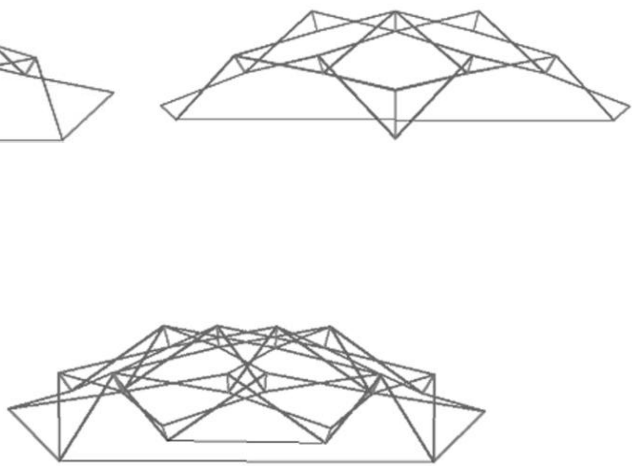

Fig. 13. The projections of the ultimate deployable 9-sectional structure

Rys. 13. Rzuty finalnej dziewięciosegmentowej struktury rozkładalnej

The values $\mathrm{w}$ and $\mathrm{v}$ can be calculated from (17) and (18) where the values $\mathrm{u}_{2}=\mathrm{B}_{3} \mathrm{D}_{3}=\mathrm{B}_{4} \mathrm{D}_{4}, \mathrm{a}_{4}+\mathrm{a}_{5}=\mathrm{C}_{3} \mathrm{~B}_{3}=\mathrm{A}_{4} \mathrm{D}_{4}$ are calculated from the system (*). However, the value $d=B_{1} B_{3}$ is obtained on the base of the 5 -segmental structure. 


$$
\begin{aligned}
& \mathrm{w}=\sqrt{\mathrm{u}_{2}^{2}-\frac{\mathrm{d}^{2}}{4}} \\
& \mathrm{v}=\sqrt{\left(\mathrm{a}_{4}+\mathrm{a}_{5}\right)^{2}-\frac{\mathrm{d}^{2}}{4}}
\end{aligned}
$$

The projections of the ultimate deployable structure are shown in the figure (Fig. 13). The model of the shell structure along with the above deployable structure is presented in (Fig. 4).

\section{Conclusions}

Deployable structures which are built with bars of identical length and characterized by identical division caused by their flexible joins enables creating only one type of forms of shell structures. Each of such forms has to be spherical sectors of identical spans in orthogonal directions of its base horizontal plane. A differentiation of such forms results from accepting various lengths of a radius of a base sphere.

Elaborating a way of shaping such structures by the change of the division quotient of chosen bars is presented in the work. This way is the preliminary stage used for working out a method leading to increasing diversity of possible forms of the shell structures supported with deployable bar structure.

The accepted solutions do not radically increase this diversity in relation to the forms mentioned above in first conclusion. Therefore further works concerned with these problems and taking into account of the possibility of increasing the number of different lengths, divisions as well as types of auxiliary tetrahedrons are necessary.

Applying a fold-out part of a structural system of a shell structure reduces the time of the assembly because of the possibility of using: a) planes and nodes appointed by the pairs of intersecting bars to set the directrices of the shell segments, b) prefabrication [8] of this deployable part of the structural system.

\section{References}

1. Abramczyk J.: Nowe możliwości kształtowania formy przekrycia powłokowego wykonanego z blach trapezowych. 58 Konferencja Naukowa Komitetu Inżynierii Lądowej i Wodnej PAN oraz Komitetu Nauki PZITB „Rzeszów-Krynica” 2012, 300-308.

2. Reichhart A.: Geometrical and structural shaping of shells made of profiled metal sheets (in Polish). Oficyna Wydawnicza Politechniki Rzeszowskiej, Rzeszów 2002.

3. Abramczyk J.: Free forms of light gauge steel shell structures. Lightweight Structures in Civil Engineering. Proc. XVIII Intern. Sem. of IASS Polish Chapter, MICROPUBLISHER-C-P Jan B. Obrębski, Warszawa 2012, 48-53. 
4. Abramczyk J.: Multi-segment shell structures. Lightweight Structures in Civil Engineering. Proc. XVIII Intern. Sem. of IASS Polish Chapter, MICROPUBLISHER-C-P Jan B. Obrębski, Warszawa 2012, 38-47.

5. Pellegrino S.: Fifty years of progress for shell and spatial structures. IASS 2009.

6. Pellegrino S.: Deployable structures. International Centre For Mechanical Sciences No 412, Springer-Verlag Wien New York, Italy 2001.

7. Obrębski J.B.: Observations on rational designing of space structures. IASS 2004 Symposium Montpellier Shell and Spatial Structures for Models to Realization, September, Montpellier, France 2004, 24-25.

8. Abramczyk J.: Nowe możliwości kształtowania formy przekrycia powłokowego wykonanego z blach trapezowych. Inżynieria i Budownictwo, 11/2012, 605-607.

\section{ROZKLADALNE STRUKTURY JAKO PODPARCIA DLA POWLOKOWYCH PRZEKRYĆ Z BLACH FALDOWYCH}

\section{Streszczenie}

Artykuł dotyczy geometrycznego kształtowania rozkładalnych struktur prętowych przyjmowanych jako zasadnicze części kształtowanych ustrojów konstrukcyjnych przekryć powłokowych, wykonanych z przekształcanych do postaci powłokowych płaskich arkuszy blachy trapezowej. Przyjmuje się więc, że zasadniczym celem wykorzystania rozkładalnej struktury prętowej jest to, aby po jej rozłożeniu końce odpowiednich prętów sąsiednich par znalazły się w oczekiwanych wspólnych węzłach. Dopiero w kolejnym etapie montażu są podejmowane działania prowadzące do usztywnienia struktury prętowej i zamocowania do niej kierownic segmentów powłokowych, których płaszczyzny i punkty końcowe przyjmuje się w płaszczyznach i węzłach struktury prętowej. Możliwa jest też prefabrykacja takich systemów konstrukcyjnych. Działania te mogą znacząco usprawnić montaż całego ustroju konstrukcyjnego. Celowy jest montaż dodatkowych prętów i ściaggów zwiększających odporność tego ustroju na obciążenia użytkowe. Osiągnięcie przedstawionych celów jest ważniejsze niż składanie się struktury do postaci dokładnie liniowej czy rozkładanie do postaci płaskiej. Zagadnienia prezentowane w pracy stanowią podstawę dla opracowania metody geometrycznego kształtowania przekryć powłokowych z przekształcanych swobodnie do postaci przestrzennej płaskich arkuszy podpartych rozkładalnymi strukturami prętowymi. W pracy zostały wykorzystane pomocnicze, wyobrażalne i zarazem ciagłe czworościany ostrosłupowe w celu uzyskania struktur o ogólnej postaci zbliżonej do sfery. Aby otrzymać zróżnicowane oryginalne formy powłokowe, w dalszych działaniach, prowadzących do opracowania omówionej metody, należy wykorzystywać również inne rodzaje pomocniczych utworów czworościennych.

Słowa kluczowe: kształtowanie geometryczne, złożone struktury, prętowe struktury, powłokowe struktury

DOI: $10.7862 / \mathrm{rb} .2013 .1$

Przesłano do redakcji w kwietniu $2013 r$.

Przyjęto do druku w czerwcu 2013 r. 